OPEN ACCESS

Edited by:

Paul Snelgrove,

Memorial University of Newfoundland

Canada

Reviewed by:

Bailey McMeans,

University of Guelph, Canada

Katrin Iken,

University of Alaska Fairbanks, USA

*Correspondence:

Paul E. Renaud,

Akvaplan-niva, Fram Centre for Climate and the Environment,

Framsenteret, Postboks 6606

Langnes, 9296 Tromsø, Norway paul.renaud@akvaplan.niva.no

Specialty section:

This article was submitted to Marine Ecosystem Ecology, a section of the journal

Frontiers in Marine Science

Received: 01 April 2015 Accepted: 15 May 2015

Published: 05 June 2015

Citation:

Renaud PE, Løkken TS, Jørgensen LL, Berge $J$ and Johnson BJ (2015)

Macroalgal detritus and food-web subsidies along an Arctic fjord depth-gradient. Front. Mar. Sci. 2:31.

doi: 10.3389/fmars.2015.00031

\section{Macroalgal detritus and food-web subsidies along an Arctic fjord depth-gradient}

\author{
Paul E. Renaud ${ }^{1,2 *}$, Therese S. Løkken ${ }^{3,4}$, Lis L. Jørgensen ${ }^{4}$, Jørgen Berge ${ }^{2,3}$ and \\ Beverly J. Johnson ${ }^{5}$
}

${ }^{1}$ Akvaplan-niva, Fram Centre for Climate and the Environment, Tromsø, Norway, ${ }^{2}$ Department of Arctic Biology, University Centre in Svalbard, Longyearbyen, Norway, ${ }^{3}$ Faculty of Biosciences, Fisheries and Economics, UiT The Arctic University of Norway, Tromsø, Norway, ${ }^{4}$ Institute of Marine Research, Tromsø, Norway, ${ }^{5}$ Department of Geology, Bates College, Lewiston, ME, USA

Tight coupling between pelagic and benthic communities is accepted as a general principle on Arctic shelves. Whereas this paradigm has been useful for guiding ecological research, it has perhaps led to a disproportionate focus on POM and ice algae as the most likely sources of carbon for the benthic food web. Arctic shelves are complex systems, including banks, fjords, and trough systems up to $350 \mathrm{~m}$ or more in depth. In this stable-isotope study, 13 different potential carbon sources were analyzed for their contribution to the food-webs of Isfjorden, Svalbard. A mixing model with herbivorous copepods and grazing sea urchins as end-members was applied to determine the relative contributions of the most likely carbon sources to pelagic and benthic taxa. Most taxa from the benthos feed on a broad mixture of POM and macroalgal detritus, even at depths down to $410 \mathrm{~m}$. Most suspension-feeding bivalves had isotopic signals consistent with more than a 50\% contribution from kelps and rockweeds. In contrast, nearly all pelagic species had diets consistent with an overwhelming contribution of pelagic POM. These results indicate that macroalgal detritus can contribute significantly to near-shore Arctic food-webs, a trophic link that may increase if macroalgae increase in the Arctic as predicted. These weaker quantitative links between pelagic and benthic components of coastal systems highlight the need for thorough sampling of potential carbon-baselines in food-web studies. A large detrital-carbon component in diets of Arctic benthos may dampen the impacts of strong seasonality in polar primary producers, leading to higher ecosystem resilience, but may also result in lower secondary productivity.

Keywords: mixing model, particulate organic carbon, pelagic-benthic coupling, stable isotope, suspension feeder, Svalbard

\section{Introduction}

Food-web structure is a key ecosystem characteristic, describing energy flow, ecological interactions, and strength of linkages within the community (Peterson and Fry, 1987; Michener et al., 2007; Boecklen et al., 2011). This information can be used to assess ecosystem stability over seasonal and multi-annual time scales (McMeans et al., 2013; Krumhansl et al., 2014), and the potential response to extrinsic changes in the system due to climatic change, distributional shifts in key taxa, and other natural or human-induced changes. The relative 
importance of different potential food sources and the pathways of energy flow across whole communities, however, remain poorly understood in Arctic coastal environments (but see Kędra et al., 2012; McMeans et al., 2013). Coastal areas of the Arctic are likely to be the first to be impacted by predicted system change (Weslawski et al., 2010; Krause-Jensen et al., 2012; Renaud et al., in press), and understanding current foodweb properties provides the necessary baseline for predicting ecosystem functioning in a future Arctic.

The prevailing paradigm concerning most shelf ecosystems throughout the Arctic is that pelagic and benthic components are tightly coupled in terms of structure and function (Grebmeier and Barry, 1991; Ambrose and Renaud, 1995; Hobson et al., 2002; Piepenburg, 2005). Much of the evidence for this concept comes from studies conducted away from the coast. The results have been quite consistent when comparisons are made at appropriate temporal and spatial scales (Renaud et al., 2008), and they have provided a mechanistic understanding of the links between planktonic production, zooplankton grazing, dynamics of vertical flux processes, and consequences for benthic community structure and function (Dunton et al., 2005; Grebmeier et al., 2006; Morata et al., 2008; Reigstad et al., 2008; Wexels Riser et al., 2008).

The strength of the paradigm and the dramatic seasonality and magnitude of the Arctic spring bloom, however, may have to led to insufficient attention to the diverse array of other potential carbon sources. Despite the strong relevance of these other sources for coastal systems, many of the stable isotope studies of coastal food webs in the Arctic have still focused on suspended particulate organic matter (POM) as the primary food source for benthic organisms (Iken et al., 2010; Feder et al., 2011; Renaud et al., 2011; Kędra et al., 2012). Stable-isotope-based studies that have investigated sources other than POM have shown that these may contribute significantly, or even primarily, to benthic foodwebs in the Arctic. These include terrestrial carbon, either from rivers or erosion of coastal sediments (Dunton et al., 2005, 2012; Iken et al., 2010; Feder et al., 2011), and ice algae (Hobson et al., 1995; Søreide et al., 2006a; Tamelander et al., 2006). Microphytobenthos is common on both soft sediments and rocky bottoms in euphotic areas of the Arctic. In these shallow ( $>30 \mathrm{~m}$ ) waters, it has primary production rates comparable to that of pelagic phytoplankton (Glud et al., 2009; Woelfel et al., 2010; McTigue et al., 2015), but its role in benthic food-webs has not been investigated.

Surprisingly little attention has been given to the role of macroalgae in coastal food webs of the Arctic, especially considering their importance in sub-Arctic food-webs (e.g., Fredriksen, 2003), and the role organic detritus may play in promoting stability in benthic communities (Moore et al., 2004; McMeans et al., 2013). Where it has been investigated, however, kelp detritus has been shown to contribute significantly to shallow-water benthic food-webs in the Arctic (Dunton and Schell, 1987; McMeans et al., 2013) and Antarctic (Dunton, 2001; Norkko et al., 2007), and it is presumed to comprise a significant component of sedimentary organic matter found in some systems (Sokołowski et al., 2012). In temperate systems, canyons facilitate transport of dislodged kelp to the deep-sea, where it may enter the food web (Vetter and Dayton, 1998; De Leo et al., 2010). No studies have investigated the role of macroalgal detritus in deeper waters in the Arctic.

In recent years, the analysis of naturally occurring stable isotopes of carbon $\left(\delta^{13} \mathrm{C}\right)$ and nitrogen $\left(\delta^{15} \mathrm{~N}\right)$ has been a useful tool for describing food-web structure (Fry, 2007). The stable isotopes of carbon and nitrogen can help identify the relative contribution of different potential carbon sources to a consumer and establish the relative trophic position of the food-web members, respectively (Peterson and Fry, 1987). This technique has been used to support the pelagic-benthic coupling paradigm as it relates to primary carbon sources for benthic food-web components in Arctic ecosystems (Hobson et al., 1995, 2002; Iken et al., 2005; Tamelander et al., 2006; Morata and Renaud, 2008).

Fjord ecosystems in the high Arctic are useful model systems in which to study ecological processes as they include both shallow and deep-water habitats, and the oceanographic and advective regimes are often more tractable than in open shelf systems. The objectives of our study were to: (1) identify the main carbon source(s) in the Isfjorden food-web in the Svalbard Archipelago, (2) investigate how the carbon sources and trophic position of benthic organisms in Isfjorden food-webs may vary with depth, (3) investigate potential consequences of these results for variability in food web structure, and for the paradigm of Arctic pelagic-benthic coupling in general.

\section{Materials and Methods}

\section{Study Site and Sampling}

Isfjorden is the largest fjord in the Svalbard archipelago. It is $170 \mathrm{~km}$ long, $24 \mathrm{~km}$ at its widest and up to $455 \mathrm{~m}$ deep (Figure 1). It is located on the west side of the Spitsbergen island and oriented in a South-West $\left(78^{\circ} 7^{\prime} \mathrm{N}\right)$-North-East $\left(78^{\circ} 27^{\prime} \mathrm{N}\right)$ direction. The fjord is linked directly to the shelf and slope area along West Spitsbergen as it has no shallow sill at its mouth, thus permitting inflow of Atlantic Water from the West Spitsbergen Current (Nilsen et al., 2008; Forwick and Vorren, 2009). However, the inflow of Atlantic Water varies among years, with along-shore wind fields being an important factor controlling this (Berge et al., 2005). The hydrography of Isfjorden is also characterized by water masses of local origin, with surface waters from melting glaciers and river runoff, and deeper waters influenced by ice formation (Nilsen et al., 2008; Forwick and Vorren, 2009).

All samples were collected during the summer and autumn of 2012 (Figure 1, Table 1) during research cruises, mostly in the outer $30-40 \mathrm{~km}$ of the fjord, with the ships RV "Viking Explorer" (August 4-7th), RV “Johan Hjort” (August 17-23rd), and RV "Helmer Hansen" (September 22nd-October 5th). Pelagic particulate organic matter (Pelagic POM) was sampled using a rosette water sampler and filtered on pre-combusted MG/F $(0.7 \mu \mathrm{m}$ pore size, $250 \mathrm{~mL}$ sea water filtered per sample; Stations P11-P24) or pre-combusted GF/F ( $0.7 \mu \mathrm{m}$ pore size, $800-1500 \mathrm{~mL}$ sea water filtered per sample; Station HH POM) filters. The filters were first examined under a stereo microscope to remove copepods and other conspicuous zooplankton. The samples were then wrapped in aluminum foil and frozen 


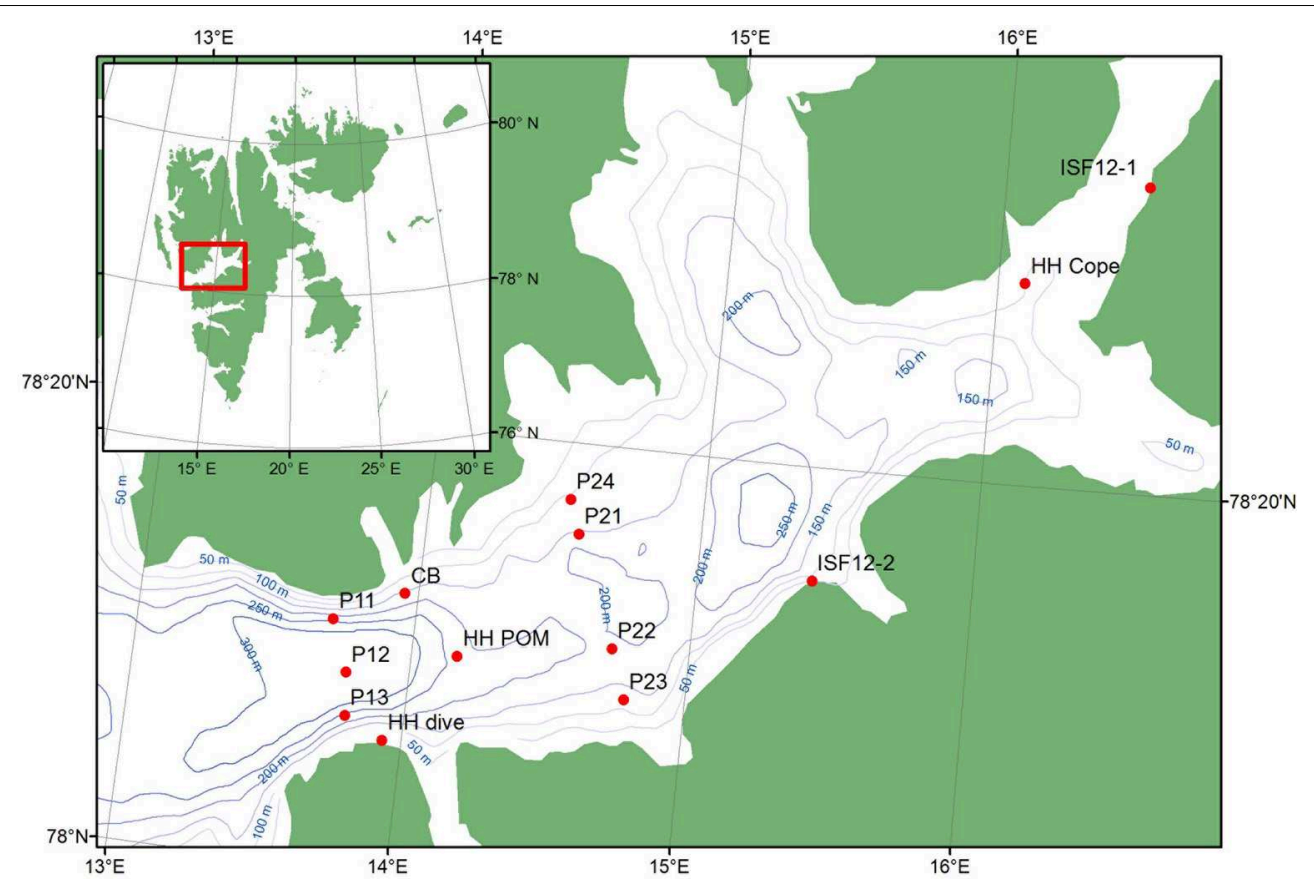

FIGURE 1 | Map of the study area of Isfjorden, Svalbard indicating sampling stations.

$\left(-20^{\circ} \mathrm{C}\right)$ until analysis. Zooplankton samples (Calanus spp. and Copepoda) were collected with a WP2 net $\left(0.25 \mathrm{~m}^{2}\right.$ opening, mesh size $180 \mu \mathrm{m})$, sorted, and frozen.

Although the marine benthic algal vegetation around Spitsbergen is not well known, Fredriksen and Kile (2012) have recently documented 83 algal taxa in Isfjorden, and a dense kelp community (Alaria esculenta, Laminaria digitata, and Saccharina latissima) on the south side of the fjord. Ten species/groups of macroalgae were collected by hand, or by using a triangular dredge or an algal rake (Station ISF12-1 and ISF122 ). One additional macroalgal sample (an additional sample of Desmarestia aculeata) was collected from an untethered buoy deployed at Sagaskjæret in early June (Station CB) and retrieved 22 September. Epiphytes were scraped off the algae and the samples were frozen in aluminum foil until analysis. Particulate organic matter from the sediment (Sediment POM) was collected from the top 1-2 cm layer of van Veen grab samples and frozen until analysis. Benthos and fish were collected using a variety of gears, depending on bottom type and functional groups targeted. A $0.1 \mathrm{~m}^{2}$ van Veen grab, a $2 \mathrm{~m}$ beam trawl $(4 \mathrm{~mm}$ mesh size), a Campelen 1800 bottom trawl towed on double warps with a $22 \mathrm{~mm}$ cod-end mesh size, and a pelagic Harstad trawl ( $8 \mathrm{~mm}$ mesh size) were used for most other sample collections (stations P11-P24). Other organisms were hand-picked from the Sagaskjæret buoy (station CB), or collected by SCUBA divers (Station HH Dive). The animals were sorted, identified, allowed to depurate (for $24-48 \mathrm{~h}$ at ambient temperatures in the dark, when appropriate), and frozen until analysis.

Whole organisms were frozen after depuration for $24-48 \mathrm{~h}$ (small organisms), and only muscle tissue was collected from fish, mollusks (except for Sepiola sp. where whole tentacles were used), and large crustaceans (e.g., decapods). One or several whole organisms constituted a single replicate sample for small crustaceans (e.g., cumaceans, amphipods, isopods) and polychaetes. For ophiuroids and asteroids, one or several arms were analyzed for each replicate. Internal viscera and gonads were analyzed for Strongylocentrotus sp. For sponges, tunicates and cnidarians, whole organisms or pieces approximately $1 \mathrm{~cm}^{3}$ were used. In the lab, POM filters were freeze-dried at $60^{\circ} \mathrm{C}$ for $24 \mathrm{~h}$. Sediment POM, animals and macroalgae were dried at $60^{\circ} \mathrm{C}$ for $48-120 \mathrm{~h}$ and stored frozen. Pelagic POM was collected from a single bottle cast at each station in August and from 3 casts $(n=3)$ in October. Five depths were sampled in the uppermost $50 \mathrm{~m}$ and then samples were taken every $50-100 \mathrm{~m}$ below this level. One sediment sample was taken from each station, and five replicates of each macroalgal source were analyzed. Replication ranged from 1 to 10 (usually 3-5) for each invertebrate and fish taxon per station, although every taxon was not collected from all stations.

\section{Stable Isotope Analysis}

The stable carbon and nitrogen isotope composition of all samples were measured using a ThermoFinnigan Delta V Advantage isotope-ratio mass spectrometer coupled to a Costech elemental analyzer via the Conflo III combustion interface in the Environmental Geochemistry Laboratory, Department of Geology, Bates College, USA between January and July 2013. Internal standards (acetanilide, caffeine, and fish muscle) were run every 8-10 samples. The reproducibility, as determined by the standard deviation of the internal standards, was $\pm 0.2 \%$ for both $\delta^{13} \mathrm{C}$ and $\delta^{15} \mathrm{~N}$. Because carbonates are isotopically enriched in ${ }^{13} \mathrm{C}$ relative to organic matter and are not necessarily 
TABLE 1 | Sampling sites and collection information.

\begin{tabular}{|c|c|c|c|c|c|c|}
\hline Station & Date (2012) & Substrate & Latitude (N) & Longitude (E) & Depth (m) & Gear \\
\hline ISF12-1 & 04 August & Rocky & $78^{\circ} 33.7$ & $16^{\circ} 32.3$ & $10-14$ & $\Delta$-dredge \\
\hline P12 & 18 August & Soft & $78^{\circ} 8.7$ & $13^{\circ} 46.5$ & $\begin{array}{l}414 \\
410 \\
422-5 \\
410 \\
60-0 \\
422-5\end{array}$ & $\begin{array}{l}\text { Beam trawl } \\
\text { Campelin trawl } \\
\text { CTD/rosette } \\
\text { Grab } \\
\text { Harstad trawl } \\
\text { WP2 }\end{array}$ \\
\hline P21 & 20 August & Soft & $78^{\circ} 16.0$ & $14^{\circ} 33.3$ & $\begin{array}{l}273 \\
272 \\
220-5 \\
272 \\
60-0 \\
270-5\end{array}$ & $\begin{array}{l}\text { Beam trawl } \\
\text { Campelin trawl } \\
\text { CTD/rosette } \\
\text { Grab } \\
\text { Harstad trawl } \\
\text { WP2 }\end{array}$ \\
\hline P22 & 17 August & Soft & $78^{\circ} 11.1^{\circ}$ & $14^{\circ} 43.2$ & $\begin{array}{l}214 \\
209 \\
220-5 \\
226 \\
60-0 \\
226-5\end{array}$ & $\begin{array}{l}\text { Beam trawl } \\
\text { Campelin trawl } \\
\text { CTD/rosette } \\
\text { Grab } \\
\text { Harstad trawl } \\
\text { WP2 }\end{array}$ \\
\hline P24 & 17 August & Mud & $78^{\circ} 17.5$ & $14^{\circ} 30.7$ & $\begin{array}{l}120 \\
148-5 \\
152 \\
100-5\end{array}$ & $\begin{array}{l}\text { Beam trawl } \\
\text { CTD/rosette } \\
\text { Grab } \\
\text { WP2 }\end{array}$ \\
\hline $\mathrm{HH}$ POM & 22 Sept & - & $78^{\circ} 10.0$ & $14^{\circ} 10.0$ & 15 & CTD/rosette \\
\hline $\mathrm{HH}$ dive & 04 October & Rocky & $78^{\circ} 5.9$ & $13^{\circ} 56.0$ & $0-25$ & Diving \\
\hline HH Cope & 05 October & - & $78^{\circ} 29.0$ & $16^{\circ} 06.0$ & $100-0$ & WP2 \\
\hline $\mathrm{CB}$ & June & - & $78^{\circ} 12.5$ & $13^{\circ} 57.1$ & 1 & Buoy \\
\hline
\end{tabular}

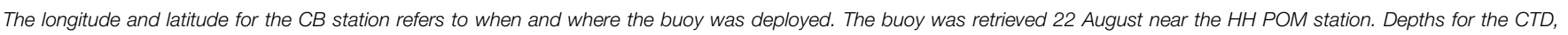
Harstad trawl, and plankton net (WP2) represent the depth range of data collection.

representative of assimilated carbon from potential food sources, these were removed from all echinoderm specimens, and from sediments, by reacting the samples in $0.2 \mathrm{M} \mathrm{H}_{3} \mathrm{PO}_{4}$ for $4 \mathrm{~h}$ at $4^{\circ} \mathrm{C}$ and then rinsing with distilled water. Because acidification of samples may lead to changes in stable nitrogen isotope values of the organic matter, the $\delta^{15} \mathrm{~N}$ values were obtained from non-acidified samples, whereas $\delta^{13} \mathrm{C}$ data came from acidified echinoderm and sediment samples (Søreide et al., 2006b; Mateo 
et al., 2008). Lipids are depleted in ${ }^{13} \mathrm{C}$ relative to other major biochemical compounds (proteins and carbohydrates), and a difference in lipid content in different organisms or tissues may lead to considerable bias in comparison of stable isotope values if this is not taken into account. A lipid correction was therefore performed after sample analysis using the lipid-normalization equation (Equation 1, Post et al., 2007) and the measured carbonto-nitrogen ratio $(\mathrm{C}: \mathrm{N})$, for all samples containing more than pure muscle tissue (i.e., non-corrected values were used for decapods and post-larval fish).

$$
\delta^{13} \mathrm{C}_{\text {normalized }}=\delta^{13} \mathrm{C}_{\text {untreated }}+((0.99) \times(\mathrm{C}: \mathrm{N})-3.32)
$$

\section{Data Analyses}

To reduce the potential number of carbon sources in later analyses, a Tukey's test (Tukey's honest significance difference test at alpha $=0.05$ ) was run on $\delta^{13} \mathrm{C}$ values for all macroalgal carbon sources following an analysis of variance (ANOVA). Also, to simplify analyses and interpretation, fauna from stations with similar depths were pooled, resulting in 4 depth zones (0$25 \mathrm{~m}$; station $\mathrm{HH}, 120-200 \mathrm{~m}$; stations P11, P13, P23, and P24, 210-270 m; stations P21 and P22, $410 \mathrm{~m}$; station P12). Previous stable-isotope studies in a nearby fjord (Kongsfjorden) indicated minimal spatial variation in food-web structure on the scale of $10 \mathrm{~s}$ of km (Renaud et al., 2011; Kędra et al., 2012), so we expect little bias from combining data from several stations into the depth intervals. Isotopic values for pelagic POM were calculated as weighted station means to account for different amounts of $\mathrm{C}$ or $\mathrm{N}$ filtered from bottles at different depths.

In order to compare trophic levels and carbon flow among organisms living at different water depths, the isotopic values for nitrogen and carbon at the base of the food-web are needed. The $\delta^{13} \mathrm{C}$ and $\delta^{15} \mathrm{~N}$ of primary producers, however, can vary significantly both among species and on spatial/temporal scales. Primary consumers have generally less variable $\delta^{13} \mathrm{C}$ and $\delta^{15} \mathrm{~N}$ values than primary producers and can represent a temporally and spatially integrated signal of the primary producers in the system (Post, 2002; Iken et al., 2010; McMeans et al., 2013).

Trophic levels (TL) for each consumer were calculated from their $\delta^{15} \mathrm{~N}$ value using Equation (2):

$$
\mathrm{TL}_{\text {consumer }}=\left[\left(\delta^{15} \mathrm{~N}_{\text {consumer }}-\delta^{15} \mathrm{~N}_{\text {base }}\right) / \Delta \delta^{15} \mathrm{~N}\right]+\mathrm{TL}_{\text {base }}
$$

where the copepod mean $\delta^{15} \mathrm{~N}$ was used as the baseline (avg \pm stdev $=7.2 \pm 0.6, n=9$ ) and represented a $\mathrm{TL}_{\text {base }}$ of 2 (as in McMeans et al., 2013). A value of $3.4 \%$ was used for the trophiclevel fractionation constant, $\Delta \delta^{15} \mathrm{~N}$ (Post, 2002; Søreide et al., 2006a).

Values of $\delta^{13} \mathrm{C}$ are generally heavier in macroalgae relative to phytoplankton, and these have been used as baselines in two end-member stable-isotope mixing-models (Fredriksen, 2003; McMeans et al., 2013). Two primary consumers were therefore chosen as baselines for calculations of the reliance on phytoplankton relative to macroalgae $(\alpha)$ in Equation (3). Copepods were chosen as a baseline for a phytoplankton grazer ( $-22.3 \%$; see Results for Figure 3), and the sea urchin Strongylocentrotus sp. from station $\mathrm{HH}(0-25 \mathrm{~m}$, where it is likely to exhibit a grazing strategy) was chosen as baseline for the macroalgal grazer ( $-15.7 \%$; see Results for Figure 3).

$$
\begin{aligned}
\alpha= & \left(\delta^{13} \mathrm{C}_{\text {consumer }}-\left[\Delta^{13} \mathrm{C} \times\left(\mathrm{TL}_{\text {consumer }}-\mathrm{TL}_{\text {baseline }}\right)\right]\right. \\
& \left.-\delta^{13} \mathrm{C}_{\text {Strongylocentrotus }}\right) /\left(\delta^{13} \mathrm{C}_{\text {Copepoda }}\right. \\
& \left.-\delta^{13} \mathrm{C}_{\text {Strongylocentrotus }}\right)
\end{aligned}
$$

where $\Delta^{13} \mathrm{C}$ was set to $4 \%$ for the first trophic step (Hobson et al., 1995) and 1\%o thereafter (Renaud et al., 2011; Kędra et al., 2013), $\mathrm{TL}_{\text {base }}$ is 2 and $\mathrm{TL}_{\text {consumer }}$ is the result of thecalculated trophic level from Equation (2). The percentage contribution of phytoplankton/POM integrated into the ${ }^{13} \mathrm{C}$ isotopic signature in a consumer, therefore, is $100 \times \alpha$.

\section{Results}

\section{Carbon Sources in the Isfjorden System}

Thirteen different potential carbon sources were sampled and analyzed for their contribution to the benthic and pelagic foodwebs of Isfjorden. These included sampling of POM on two dates, sediment POM, and 10 algal taxa, groups, or regions of the algal thallus. On an individual replicate level, values for all potential carbon sources varied considerably (Figure 2). August POM was highly variable in both $\delta^{13} \mathrm{C}$ and $\delta^{15} \mathrm{~N}$, with station means between -27.0 and $-23.0 \%\left(\delta^{13} \mathrm{C}\right)$ and $-0.4-8.8 \%$ $\left(\delta^{15} \mathrm{~N}\right)$. The single POM sampling in October fell in the middle of this range. Station means for sediment POM ranged from -24.3 to $-19.0 \%$ o $\left(\delta^{13} \mathrm{C}\right)$ and 3.6 to $6.5 \%\left(\delta^{15} \mathrm{~N}\right)$. Red algae were highly depleted in ${ }^{13} \mathrm{C}$, with values less than $-28.0 \%$ (Figure 2). Brown algae as a group were highly variable in $\delta^{13} \mathrm{C}$, but less so in $\delta^{15} \mathrm{~N}$ (Supplementary Material Table S1).

The Tukey's HSD test following the ANOVA on macroalgal $\delta^{13} \mathrm{C}$ values identified two distinct groups of brown algae: Chorda filum, Desmarestia aculeata, and Saccharina latissima (Phaeophyceae 1); and Devaleraea ramentacea, Fucus sp., Laminaria digitata stipe, L. digitata lamina, and Pylaiella littoralis/Ectocarpus fasciculatus (Phaeophyceae 2), and identified two red algal groups (Phycodres and Polysiphonia/Rhodomela, and Odontothalia) (Rhodophyta) groups as distinct (Figure 2). These carbon-source classes formed the basis for a graphical assessment (Figure 3) of which carbon sources contributed most to benthic and pelagic food-webs. Source classes were plotted along with their predicted fractionation trajectories, and with presumed (from literature information) primary consumers. For simplicity, the Rhodophyta were pooled in this figure, although they were identified as separate groups by the Tukey's test. A fractionation of $4 \%$ for $\delta^{13} \mathrm{C}$ between the first two trophic levels, and then $1 \%$ between trophic level 2 and trophic level 3 was used to construct trajectories based on the mean values for each source/source group (Hobson et al., 1995; Nadon and Himmelman, 2006). The trophic level fractionation used for $\delta^{15} \mathrm{~N}$ was $3.4 \%$.

The pelagic grazer groups Copepoda and Calanus spp. had identical $\delta^{15} \mathrm{~N}$ values and dual isotope values that fell near the hypothetical fractionation trajectory for pelagic POM in the respective collection seasons, suggesting POM is the primary 


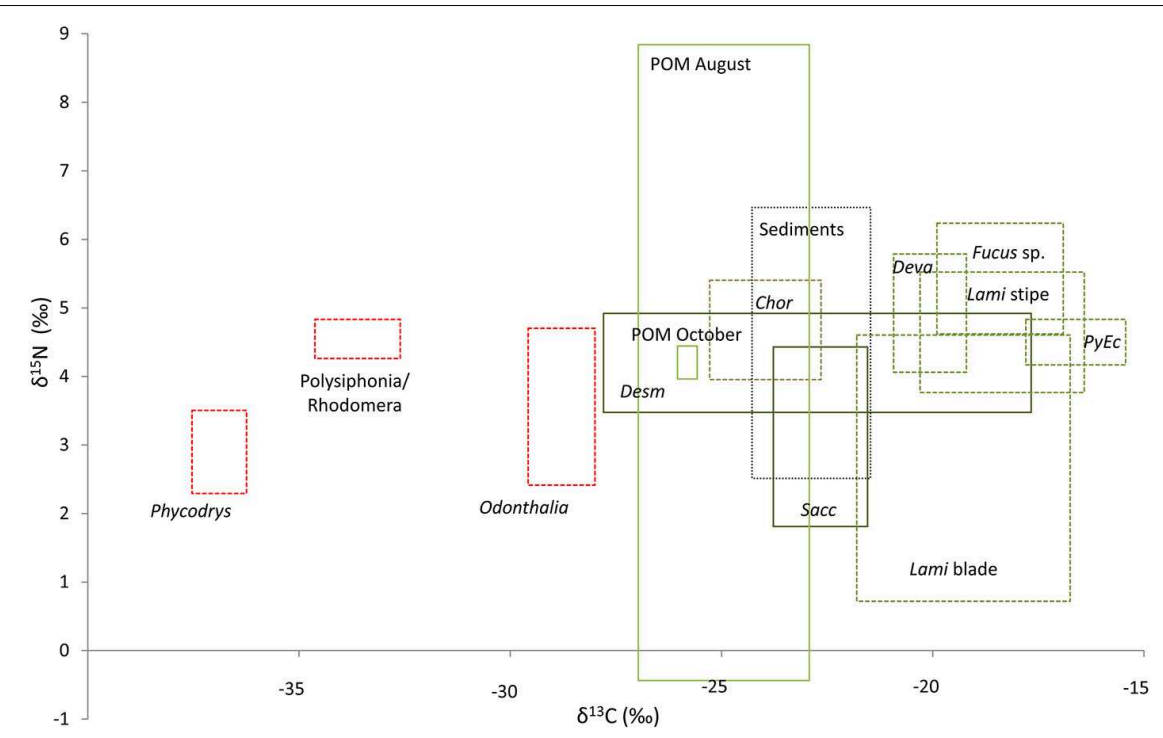

FIGURE 2 | Isotopic distribution of all collected carbon sources. The boxes represent the full range of data from all replicates of the respective carbon sources (maximum and minimum $\delta^{13} \mathrm{C}$ and $\delta^{15} \mathrm{~N}$ ). Abbrevations are as follows Chor, Chorda filum; Desm, Desmarestia aculeata; Deva, Devaleraea ramentacea; Lami blade, lamina of Laminaria digitata; Lami stipe, stipe of Laminaria digitata; PyEc, Pylaiella littoralis/Ectocarpus fasciculatus; and Sacc, Saccharina latissima.

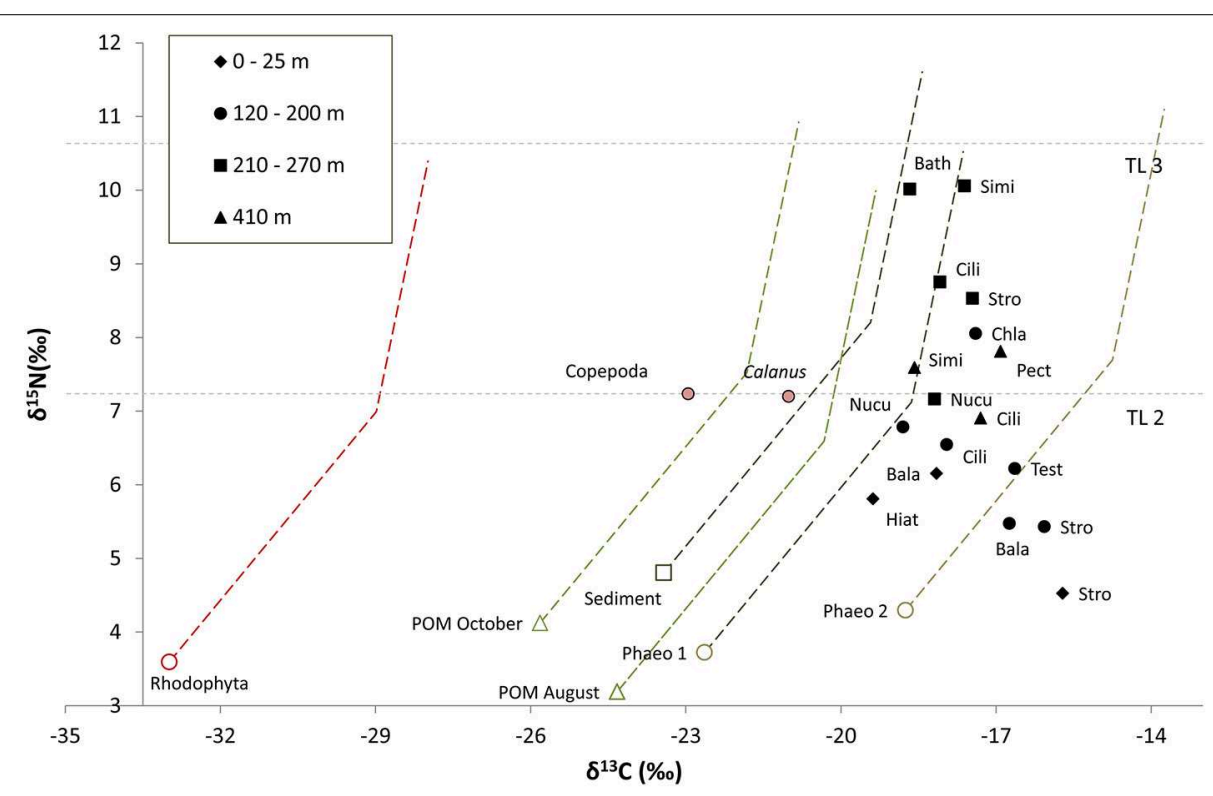

FIGURE 3 | Isotopic composition of carbon sources (average values of all stations) and primary consumers (average values per depth interval). Dashed lines represent fractionation lines between potentail carbon sources and primary consumers assuing an intial fractionation of $4 \%$ between TL 1 and 2 and then $1 \%$ between TL 2 and 3 for $\delta^{13} \mathrm{C}$, and $3.4 \%$ for $\delta^{15} \mathrm{~N}$ between each TL. Copepoda and POM August are the averages of all Copepoda and POM samples, respectively from stations P11-P24 (collected in August). Calanus spp. is the average of the Calanus from station $\mathrm{HH}$ Cope (collected in October). Both Calanus and Copepoda are assigned trophic level 2 (TL 2). Abbrevations are as follows; Bala, Balanus sp.; Bath, Bathyarca glacialis; Chla, Chlamys islandica; Cili, Ciliatocardium ciliatum; Hiat, Hiatella arctica; Nucu, Nuculana pernula; Stro, Strongylocentrotus sp.; and Test, Testidunalia testidunalis. Phaeophyceae 1 consists of the algal species Chorda filum, Desmarestia aculeata, and Saccharina latissima, and Phaeophyceae 2 consists of Devaleraea ramentacea, Fucus sp., Pylaiella littoralis/Ectocarpus fasciculatus, and Laminaria digitata (stipe and lamina). Horizontal lines indicate the $\delta^{15} \mathrm{~N}$ position of TL 2 and 3 based on Calanus values. carbon source for these taxa. All benthic primary consumers were more enriched in $\delta^{13} \mathrm{C}$ than trajectories predicted for Rhodophyta, pelagic POM, and sediment POM. They did, however, have carbon signatures consistent with significant contributions of the brown algal groups Phaeophyceae 1 and Phaeophyceae 2 (Figure 3). The range in $\delta^{15} \mathrm{~N}$ for the presumed 


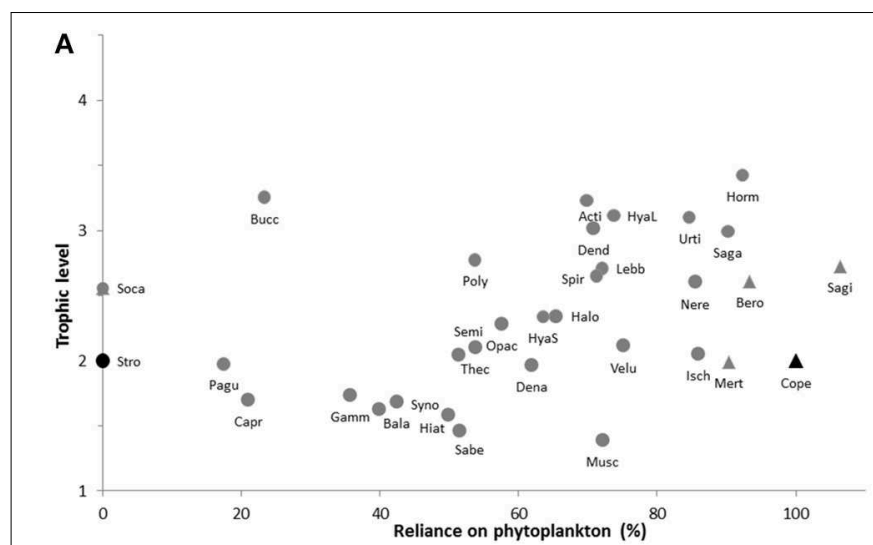

C

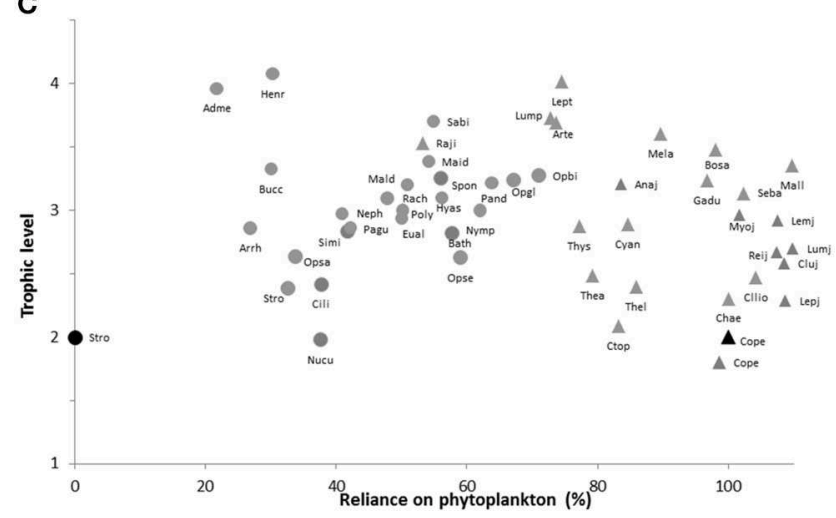

FIGURE 4 | Plots of trophic level vs. \% reliance of the organism's diet on phytoplankton for benthic (circles) and pelagic (triangles) taxa. Results are from mixing models with endpoints assuming

Copepods feeding on $100 \%$ phytoplankton and Strongylocentrotus from

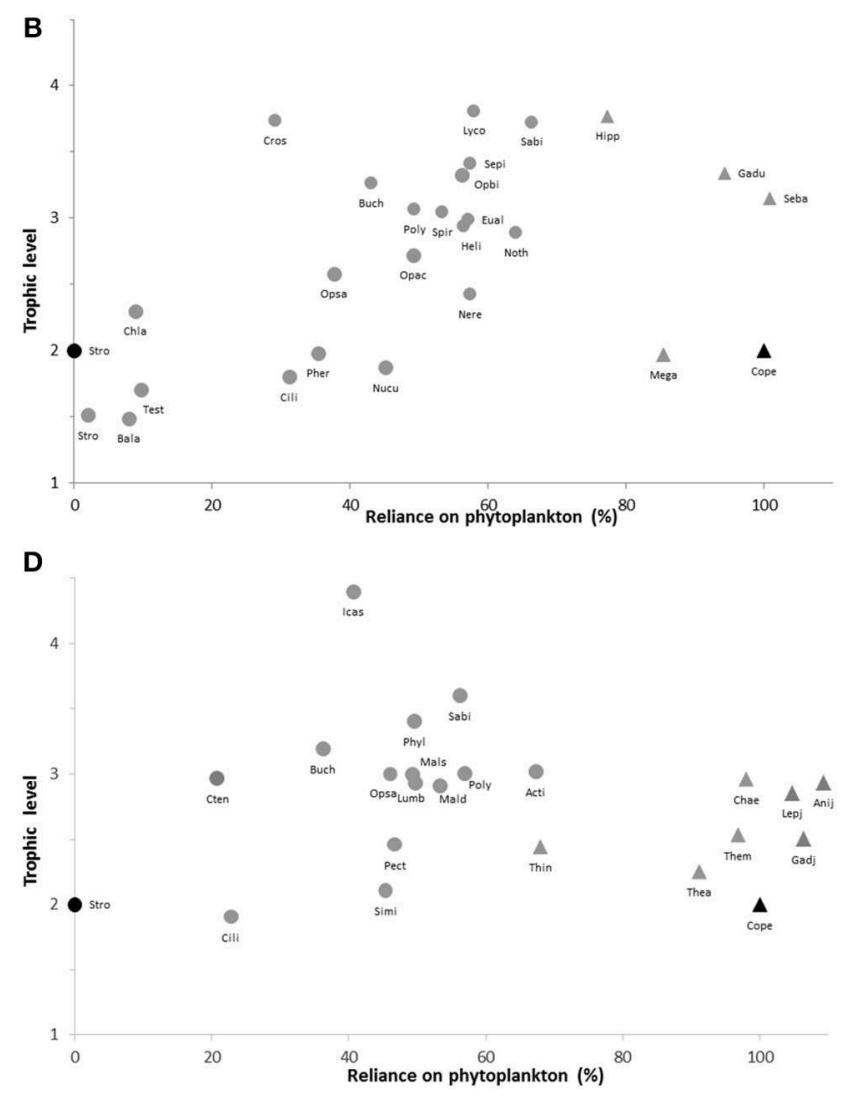

0 to $25 \mathrm{~m}$ depth feeding on 100\% Phaeophyceae 2 material (these are marked in black symbols on each plot). (A): 0-25m, (B): 120-200m, (C): 210-270m, (D): $410 \mathrm{~m}$. Symbol-label abbreviations clarified in Appendix. primary consumers is relatively high, ranging over more than $5.6 \%$; the lowest value was found in Strongylocentrotus sp. at $0-25 \mathrm{~m}\left(\delta^{15} \mathrm{~N}=4.5 \%\right)$ and the highest value was found for Similipecten greenlandicus at $210-270 \mathrm{~m}\left(\delta^{15} \mathrm{~N}=10 \% 0\right)$. The $\delta^{15} \mathrm{~N}$ values for primary consumers were generally higher from deeper stations (210-270 and $410 \mathrm{~m}$ ) than from the shallower stations (0-25 and 120-200 m), but replication levels were not sufficent for statistical testing (Figure 3).

\section{Variation in Carbon Source with Depth: A Mixing-model Study}

Carbon and nitrogen stable isotope values were determined for a total of 526 samples from 105 taxa (plus sediment and POM), and faunal values ranged from -24.1 to $-16.2 \%$ for $\delta^{13} \mathrm{C}$ and $5.0-$ $15 \%$ for $\delta^{15} \mathrm{~N}$, with calculated mean trophic-levels ranging from 1.4 (Musculus sp. at 0-25 m) to 4.4 (Icasterias panopla at $410 \mathrm{~m}$ ). Taxon means for each station are provided in the Supplementary Material (Table S1).

The relative contribution of POM vs. Phaeophyceae 2 in the $\delta^{13} \mathrm{C}$ signatures of benthic organisms varied considerably, from $0 \%$ (Socarnes sp. from 0 to $25 \mathrm{~m}$ depth) to over $92 \%$ (Hormathia nodosa, $0-25 \mathrm{~m}$ ), whereas all pelagic organisms derived over $80 \%$ of their carbon signature from POM, except for the hyperbenthic bobtail squid Sepiola sp. (58\% from 120 to $200 \mathrm{~m}$ ) and the krill Thysanoessa inermis $(68 \%, 410 \mathrm{~m})$ (Figure 4). Larval/post-larval fish of a variety of species had a POM dietary-component of 90 to $>100 \%$ (values $>100 \%$ indicate ianccuracies in fitting mixing models to all taxa at all locations). At the shallowest station (0-25 m, Figure 4A), the reliance on phytoplankton as a carbon source varied from under $20 \%$ to over $70 \%$ for benthic organisms at or below trophic level 2. Barnacles and filter feeding polychaetes and bivalves (Sabellidae and Hiatella arctica) had a signature consistent with assimilating more than $48 \%$ macroalgal material. At the highest trophic levels, benthic predators and scavengers like the spider crab Hyas araneus and the decapod Lebbeus polaris received $60-75 \%$ of their carbon from POM, while the large predatory/scavenging gastropod Buccinum sp. derived only $23 \%$ of its carbon from POM. Four actinarians (Hormathia nodosa, Urticina eques, Sagartia troglodytes, and Actinia equina) were also among the taxa at the highest trophic levels and had POM shares of between 65 and $92 \%$.

A large share (55-69\%) of macroalgal carbon was also observed in suspension feeding bivalves (Chlamys islandica, Nuculana pernula, Ciliatocardium ciliatum) between 120 and $200 \mathrm{~m}$ (Figure 4B), whereas predatory fish, decapods, and 
echinoderms exhibited diets of mixed carbon source (30$80 \%$ POM). A similar pattern was observed at the $210-270 \mathrm{~m}$ depth range (Figure 4C), where benthic suspension feeders generally had a reliance on POM of $<50 \%$. Pelagic crustaceans (Thysanoessa sp., Themisto spp.) and jellies (ctenophores, Cyanea capillata) were found to have a carbon signature consistent with a 5-25\% contribution from Phaeo 3. Most larval fish species had a reliance on POM between 100 and $110 \%$, whereas other pelagic fish were over $80 \%$ consistent with a phytoplankton carbon source (Figure 4C). Top benthic predators in this depth range had variable contribution from POM: predatory/scavenging gastropods and sea stars (Admete sp., Buccinum sp., Henricia sp.) had low values consistent with an over $70 \%$ contribution of Phaeo 3 material, while benthic-feeding fish, decapods, and ophiuroids (Rajidae, Lumpenus lampretaeformis, Artediellus atlantica, Sabinea septemcarinata, Ophiacantha bidentata, and Ophioscolex glacialis) had 50-75\% reliance on phytoplankton (Figure 4C). Finally, a similar trend toward relatively low POM contribution to benthic suspension feeders and some top predators, and consistently high reliance on POM for most pelagic taxa, was observed at the $410 \mathrm{~m}$ station (Figure 4D). One notable exception was the krill Thysanoessa inermis having over $30 \%$ contribution of Phaeo 3 material in its $\delta^{13} \mathrm{C}$ signature. In general, deposit and scavenging polychaetes of trophic level 2.5-3.5 (maldanids, polynoids, lumbrinereids, nephtyids) had a POM contribution of $40-60 \%$ at all depth intervals (Figure 4).

\section{Discussion}

\section{Carbon Sources in the Isfjorden System}

Arguably, the most important knowledge gap in Arctic marine food-web studies is the identification of spatial and temporal variability in primary carbon sources. The 12 different potential carbon sources (plus one sampled in two seasons) sampled in this study represent the largest such investigation performed in the Arctic. The range in $\delta^{13} \mathrm{C}$ signatures of over $20 \%$ suggests isotopic analysis is a valuable tool for identifying carbon source. As in other studies (Hobson et al., 1995; Dunton, 2001; Nadon and Himmelman, 2006), red algae were severely depleted in $\delta^{13} \mathrm{C}$. Brown algal groups, POM, and sediment organic matter had ratios varying by more than $10 \%$. Sediment POM in our study had a $\delta^{13} \mathrm{C}$ signature similar to that of POM, unlike in the study of Sokołowski et al. (2012) from Hornsund, a fjord south of Isfjorden on Svalbard. They found the signature to fall between POM and macroalgae, and suggested this was the main carbon source for the benthos.

Our study did not sample three sources that may contribute to Arctic food-webs: terrestrial carbon, ice algae, and microphytobenthos. In addition, ${ }^{13} \mathrm{C}$-enrichment of POM during sinking may provide the heavy carbon signal seen in the benthos. Minimal sea-ice has been observed in Isfjorden for well over 5 years, and there is little terrestrial vegetation around the fjord, suggesting these two sources may contribute very little to food webs here. Microphytobenthos, however, may exhibit photosynthetic rates equaling or exceeding that of phytoplankton in shallow water $(<30 \mathrm{~m})$ Arctic systems (Glud et al., 2002, 2009; Woelfel et al., 2010). This source would likely provide a heavy $\delta^{13} \mathrm{C}$ signal analogous to that from brown macroalgae (Nadon and Himmelman, 2006), but this source was not sampled in this study. It is, however, questionable as to whether microphytobenthos could be relevant at the deep stations in Isfjorden. Estimates of production in shallow waters in Arctic systems are comparable to pelagic productivity (Woelfel et al., 2010), but both pelagic and macroalgal productivity will exceed these values in deeper waters. A final possibility is that isotopic enrichment of pelagic POM during sinking may have a similar signal to that of brown macroalgae. The enrichment necessary over a maximum depth of $400 \mathrm{~m}$ would be $\geq 6 \%$, and the literature shows mixed findings as the change in carbon isotope values of POM with depth: from an enrichment of $4 \%$ to strong depletion of over 5\%o (Nakatsuka et al., 1997; Tamelander et al., 2006; Nerot et al., 2012). So while this remains a possibility, it is not clear how likely it is.

To identify candidate carbon sources for our mixing model, we investigated fractionation trajectories using an initial fractionation between primary producer and primary consumer of $4 \%$. This is recommended in such analyses by Nadon and Himmelman (2006), as such a fractionation between POM and benthic suspension feeders has been observed in numerous studies (Hobson et al., 1995; McMahon et al., 2006; Tamelander et al., 2006; Renaud et al., 2011). Using a 1\%o fractionation for this first step would suggest a higher contribution of macroalgal material (or other source with a heavy signature), than POC even for pelagic grazers (Calanus). From the fractionation trajectories we used, however, the most likely carbon source for grazing zooplankton was identified to be POM. The other end-member chosen was Phaeo 3, including a group of abundant nearshore taxa including kelp (Laminaria digitata) and rockweeds (Fucus spp.). The sea urchin Strongylocentrotus sp. had carbon isotopic values consistent with this group of algae making up a large portion of its diet, although its $\delta^{15} \mathrm{~N}$ values were strangely depleted for what would be expected from an organism at TL2. Perhaps internal fractionation pathways, or even relative contributions of somatic vs. reproductive tissue, may be responsible, but we have no information to identify the cause. Regardless, this does not affect the $\alpha$ values calculated from the mixing model as those are based only on the $\delta^{13} \mathrm{C}$ value and the assumption that sea urchins should be at around TL2 in shallow waters.

There is some suggestion that ${ }^{13} \mathrm{C}$-enriched sources may contribute to the food web in our study since some primary consumers are more enriched than suggested by the trajectory for kelp. Recent studies indicate that aging of kelp thalli for 1-2 weeks can enrich the $\delta^{13} \mathrm{C}$ signature by approximately 1 per mil (C. Buchholz, Alfred-Wegener-Institute, pers. comm.), suggesting aged macroalgal detritus as one pathway to a heavier food source. As discussed above, microphytobenthos may be another. But most primary consumers, including a known grazer of these macroalgae in shallow waters (Strongylocentrotus sp.), have signatures consistent with a significant contribution of Phaeo 3, even at deeper stations. A similar pattern was found for benthic suspension-feeders in Hornsund at depths less than $100 \mathrm{~m}$ (Sokołowski et al., 2012). It is important to keep in mind 
that a two-member mixing model is still a simplification of actual diet mixtures from which benthic fauna will derive their $\delta^{13} \mathrm{C}$ signatures.

\section{Variation in Carbon Source and Trophic Position with Depth}

Carbon-isotope signatures of many benthic organisms were consistent with significant contributions of brown macroalgal material at all depths investigated. This was particularly evident for lower trophic level organisms, both grazers and suspension feeders, but at least one predator and scavengers at a trophic level of between 3 and 4 exhibited a $>70 \%$ share of Phaeo 3 organic matter at each depth interval. Previous benthic food-web studies in a nearby fjord did not find much difference in $\delta^{13} \mathrm{C}$ from primary consumers up through the food chain (Renaud et al., 2011; Kędra et al., 2013), and carbon sources were interpreted to be wither pelagic POM or terrestrial carbon. In this study, however, we sampled from a greater range of water depths, and this may partly explain the contrast in results. The relative abundance of macroalgae in the two fjords is not known.

Ours is the first study indicating that macroalgal detritus can contribute significantly to both shallow-water and deep-water food-webs in the Arctic. In temperate systems, kelp detritus has been found to have a significant impact on benthic food-webs where submarine canyons serve as a conduit for export to the deep sea (Vetter and Dayton, 1998; De Leo et al., 2010). The proximity of deep waters $(>400 \mathrm{~m})$ to macroalgal habitat in steep-sided fjords may be responsible for the strong macroalgal signal in deep-fjord benthos since the fjord geomorphology can facilitate rapid resuspension of both detrital macroalgal material and deposition onto the fjord bottom of whole thalli dislodged by storms.

Carbon from the kelp Laminaria hyperborea plays an important role in near-shore systems in sub-Arctic Norway, where it was found to constitute the ultimate carbon source for benthic organisms exhibiting several different types of feeding strategies (Fredriksen, 2003). A wide range (0-100\%) in the proportion of kelp carbon in the diets of benthic organisms was found from Arctic (Dunton and Schell, 1987) and Antarctic (Dunton, 2001) benthos. In contrast to their results, we found few benthic taxa with under $30 \%$ macroalgal-derived carbon, but we collected few samples from the groups that they documented as having high POM contributions (bryozoans, soft corals, sponges). McMeans et al. (2013) investigated the food-webs at a shallow-water site near Baffin Island, Canadian Archipelago, and found that benthic grazers (limpets, snails) nearly exclusively fed on macroalgae, and a polychaete of trophic level 2.4 had an isotopic signal indicating a reliance on macroalgae of over $85 \%$. Other benthic taxa, from suspension-feeding bivalves to predatory gastropods, had only $30-60 \%$ reliance on macroalgal carbon in their diet. We replicated their mixing-model approach in our study and found comparable results, but a stronger reliance on macroalgae throughout the food web, including a $50-80 \%$ share of macroalgae in suspension feeding bivalves and a $65-80 \%$ share in predatory gastropods, regardless of depth. Our findings of very high reliance on POM for pelagic taxa were also similar to those of McMeans et al. (2013).
Based on their mixing-model results, McMeans et al. (2013) proposed a conceptual model of food-web structure, whereby a few lower trophic-level taxa from pelagic and benthic food-webs feed nearly exclusively on POM and macroalgae, respectively, and other taxa derive their nutrition from a broad mixture of the two (or more) carbon sources. This, they suggested, leads to a unimodal curve in the relationship between trophic level and percent reliance on POM, with sharp slopes between 0 and 20\% POM and 80 and 100\% POM. Our data are consistent with this concept of multiple energy channels in coastal marine food-webs and the high reliance of pelagic organisms on POM, but also suggest that in coastal systems favoring down-slope transport of macroalgal material, the pattern can extend to deep waters. Further, we found little support for a strong unimodal signal at most depths (see Figure 4). Some benthic taxa at the highest trophic levels were found with more than $80 \%$ reliance on macroalgae, while others had $30 \%$ or less. In addition, suspension-feeding bivalves in our study had variable, but often larger, shares of macroalgal material than found by McMeans et al. (2013). Our results are similar, however, in that many benthic taxa with trophic levels above 2.5 had a broad mixture of carbon sources in their diets. The few pelagic taxa that did not strictly follow this pattern, Sepiola sp. and Thysanoessa inermis (from $410 \mathrm{~m}$ ), probably feed to some degree near the sea floor. The small squid is hyperbenthic and likely preys on epibenthic organisms and thus has a signal consistent with benthic carbon sources. Genetic analyses of gut contents from another species of krill (Meganyctophanes norvegica) identified significant amounts of sediment-associated prey, indicating a previously unknown carbon pathway linking the benthos to the pelagic food web (Cleary et al., 2012) that may be relevant in Isfjorden as well.

Studies from only two locations (Baffin Island, Isfjorden) are not sufficient to adequately test this conceptual model, however. The unimodal shape of this distribution is dependent upon the taxa sampled in the study, and the degree of opportunism/specialization (at the individual, location, or species level) in the taxa chosen. Local variability in transport and depositional processes will also affect the carbon-source signal in these taxa. Tissue turnover-time is another issue that may affect the shape of this distribution. Differential motility and/or highly omnivorous diets may also play some role in determining the ultimate carbon sources for benthic feeders at higher trophic levels: fish, decapods, and large echinoderms generally have a higher proportion of POM in their diets. Relatively sessile actinarians also exhibit a high proportion (50-85\%) of POM, but this is most likely due to the large proportion of zooplankton, and even picoplankton, in their diets (Sokołowski et al., 2012).

\section{Consequences and Implications for Arctic Food-webs}

The paradigm of tight pelagic-benthic coupling on Arctic shelves has been a valuable tool and null model guiding studies over the past several decades. When pelagic and benthic parameters (stocks and processes) varying on similar scales are compared, it has shown remarkable consistency (Renaud et al., 2008), and may be useful in management-related questions by helping to identify hotspots of system productivity (Link et al., 2011; 
Darnis et al., 2012; Kędra et al., 2012; Conlan et al., 2013; Roy et al., 2014). The importance of this link, however, may affect sampling design and hinder objective interpretation of data. Bivalve growth patterns have been suggested to be of high value as a proxy of climate in the Arctic due to the ability to link growth of filter feeders (Ambrose et al., 2005; Carroll et al., 2011) to presumed variability in pelagic productivity. At all depths in coastal Isfjorden, however, filter-feeding bivalves (Ciliatocardium, Hiatella, Chlamys, Similipecten) have a signature consistent with over $50 \%$ assimilation of macroalgal carbon. These results do not invalidate the climate proxy studies, but the understanding of multiple nutritional channels in the coastal benthos may improve data interpretation.

A second example of where the pelagic-benthic coupling paradigm may improperly influence ecological studies on Arctic shelves is where food-web studies have focused on POM (and perhaps ice algae) as the most likely sources of carbon for the food web. Particularly in coastal systems, macroalgae (and other sources) may contribute equally or even more. POM and sediments are often sampled in benthic food-web studies, and where faunal signatures are not consistent with a POM source, terrestrial carbon input is suggested to be the next most likely candidate source (Iken et al., 2010; Feder et al., 2011; Renaud et al., 2011; Kędra et al., 2012). This argument is usually invoked to explain lighter $\delta^{13} \mathrm{C}$ signatures than those from POM, whereas heavier signatures have invoked the potential role of ice algae (Søreide et al., 2006a; Tamelander et al., 2006), a source not tested but also not likely present in largely ice-free Isfjorden. Our study indicates quantitatively how benthic macroalgae can reduce the relative contributions of pelagic food sources to benthic components of coastal systems, even down to $400 \mathrm{~m}$. This information highlights the need for thorough sampling of potential carbon-baselines in food-web studies, and use of mixing models to determine relative contributions of different carbon sources. Further, studies lacking good resolution of potential sources should take care when using a single second trophic-level organism as a proxy for the baseline since our results indicate that use of copepods vs. suspension-feeding bivalves would lead to quite different interpretations of food-web structure.

Detrital carbon in sediments has been suggested to promote stability in food-webs (Moore et al., 2004; McMeans et al., 2013), and may dampen the impacts of seasonal fluctuations in deposition of fresh phytodetritus (Norkko et al., 2007). This is likely to be particularly relevant in high-latitude systems where productivity occurs in discrete pulses. Taxa exhibiting omnivory and seasonal switching in nutritional channels will be able to

\section{References}

Ambrose, W. G. Jr., and Renaud, P. E. (1995). Benthic response to water column productivity patterns: evidence for benthic-pelagic coupling in the Northeast Water Polynya. J. Geophys. Res. Oceans 100, 4411-4421.

Ambrose, W. G., Von Quillfeldt, C., Clough, L. M., Tilney, P. V. R., and Tucker, T. (2005). The sub-ice algal community in the Chukchi Sea: large- and small-scale patterns of abundance based on images from a remotely operated vehicle. Polar Biol. 28, 784-795. doi: 10.1007/s00300-005-0002-8 best take advantage of such a sedimentary carbon pool. We show that much of the benthic community sampled contains a mixture of carbon sources, regardless of functional group, even during late summer. Even suspension feeders, usually presumed to feed primarily on phytodetritus, are clearly incorporating significant amounts of resuspended macroalgal detritus. A system where pulses of higher-quality food sources are buffered by abundant detrital sources may enhance biodiversity if it leads to reduced competition and well-developed recycling processes.

Macroalgae in both Arctic and Antarctic systems are predicted to increase with warming temperatures and reduced sea-ice cover (Krause-Jensen et al., 2012; Clark et al., 2013) and this may already be occurring in some areas (Węsławski et al., 2011; Kortsch et al., 2012). If recent results (McMeans et al., 2013; this study) are applicable to wider area of the Arctic, greater macroalgal production could set off a series of complex changes in coastal benthos, whereby sessile invertebrates can be replaced by habitat-engineering macroalgae and associated invertebrates, and fresh macroalgal and detrital food-webs are enhanced (Kortsch et al., 2012; Krause-Jensen et al., 2012; Clark et al., 2013). Reliance on recycling-based pathways, however, may reduce secondary production and negatively impact the value of coastal benthic communities as feeding resources for fish, seabirds, and mammals.

\section{Acknowledgments}

This work could not have been accomplished without the efforts of the captains and crews of the research vessels Viking Explorer, Johan Hjort, Helmer Hanssen. Many colleagues assisted with sampling and processing, including H. Andrade, R. Bannister, A. Bjørge, B. Gulliksen, E. Eriksen, S. Fredriksen, T. Gabrielsen, B. Goundie, K. Heggland, O. Lyubina, T. Prokhorova, B. Seim, K. Sivertsen, D. Vogedes, L. Wilson, and E. Åström. Considerable funding was provided by the Institute of Marine Research and the Fjord and Coast Flagship of the Fram Centre for Climate and the Environment. Additional support came from Akvaplan-niva, Bates College, and UiT The Arctic University of Norway. We are grateful for graphics assistance from $M$. Daase and comments from W. Ambrose on an early version of the manuscript.

\section{Supplementary Material}

The Supplementary Material for this article can be found online at: http://journal.frontiersin.org/article/10.3389/fmars. 2015.00031/abstract 
regulation in the Arctic bivalve Serripes groenlandicus. J. Mar. Syst. 88, 239-251. doi: 10.1016/j.jmarsys.2011.04.010

Clark, G. F., Stark, J. S., Johnston, E. L., Runcie, J. W., Goldsworthy, P. M., Raymond, B., et al. (2013). Light-driven tipping points in polar ecosystems. Glob. Change Biol. 19, 3749-3761. doi: 10.1111/gcb.12337

Cleary, A. C., Durbin, E. G., and Rynearson, T. (2012). Krill feeding on sediment in the Gulf of Maine (North Atlantic). Mar. Ecol. Prog. Ser. 455, 157-172. doi: 10.3354/meps09632

Conlan, K., Hendrycks, E., Aitken, A., Williams, B., Blasco, S., and Crawford, E. (2013). Macrofaunal biomass distribution on the Canadian Beaufort Shelf. J. Mar. Syst. 127, 76-87. doi: 10.1016/j.jmarsys.2013.07.013

Darnis, G., Robert, D., Pomerleau, C., Link, H., Archambault, P., Nelson, R. J., et al. (2012). Current state and trends in Canadian Arctic marine ecosystems: II. Heterotrophic food web, pelagic-benthic coupling, and biodiversity. Clim. Change 115, 179-205. doi: 10.1007/s10584-012-0483-8

De Leo, F. C., Smith, C. R., Rowden, A. A., Bowden, D. A., and Clark, M. R. (2010). Submarine canyons: hotspots of benthic biomass and productivity in the deep sea. Proc. R. Soc. B 277, 2783-2792. doi: 10.1098/rspb.2010.0462

Dunton, K. H. (2001). $\delta^{15} \mathrm{~N}$ and $\delta^{13} \mathrm{C}$ measurements of Antarctic Peninsula fauna: trophic relationships and assimilation of benthic seaweeds. Am. Zool. 41, 99-112. doi: 10.1093/icb/41.1.99

Dunton, K. H., Goodall, J. L., Schonberg, S. V., Grebmeier, J. M., and Maidment, D. R. (2005). Multi-decadal synthesis of benthic-pelagic coupling in the western arctic: role of cross-shelf advective processes. Deep Sea Res. Part II 52, 3462-3477. doi: 10.1016/j.dsr2.2005.09.007

Dunton, K. H., and Schell, D. M. (1987). Dependence of consumers on macroalgal (Laminaria solidungula) carbon in an arctic kelp community: $\delta^{13} \mathrm{C}$ evidence. Mar. Biol. 4, 615-625.

Dunton, K. H., Schonberg, S. V., and Cooper, L. W. (2012). Food web structure of the alaskan nearshore shelf and estuarine lagoons of the Beaufort Sea. Estuar Coast. 35, 416-435. doi: 10.1007/s12237-012-9475-1

Feder, H., Iken, K., Blanchard, A., Jewett, S., and Schonberg, S. (2011). Benthic food web structure in the southeastern Chukchi Sea: an assessment using $\delta^{13} \mathrm{C}$ and $\delta^{15} \mathrm{~N}$ analyses. Polar Biol. 34, 521-532. doi: 10.1007/s00300-010-0906-9

Forwick, M., and Vorren, T. O. (2009). Late Weichselian and Holocene sedimentary environments and ice rafting in Isfjorden, Spitsbergen. Palaeogeogr. Palaeoclimatol. Palaeoecol. 280, 258-274. doi: 10.1016/j.palaeo.2009.06.026

Fredriksen, S. (2003). Food web studies in a Norwegian kelp forest based on stable isotope (delta ${ }^{13} \mathrm{C}$ and delta ${ }^{15} \mathrm{~N}$ ) analysis. Mar. Ecol. Prog. Ser. 260, 71-81. doi: $10.3354 / \mathrm{meps} 260071$

Fredriksen, S., and Kile, M. R. (2012). The algal vegetation of Isfjorden, Spitsbergen: revisiting Per Svendsen's site 50 years later. Polar Res. 31:17538. doi: 10.3402/polar.v31i0.17538

Fry, B. (2007). Stable Isotope Ecology. New York, NY: Springer Science \& Business Media.

Glud, R. N., Kuhl, M., Wenzhoefer, F., and Rysgaard, S. (2002). Benthic diatoms of a high Arctic fjord (Young Sound, NE Greenland): importance for ecosystem primary production. Mar. Ecol. Prog. Ser. 238, 15-29. doi: 10.3354/meps238015

Glud, R. N., Woelfel, J., Karsten, U., Kuhl, M., and Rysgaard, S. (2009). Benthic microalgal production in the Arctic: applied methods and status of the current database. Bot. Mar. 52, 559-571. doi: 10.1515/BOT.2009.074

Grebmeier, J. M., and Barry, J. P. (1991). The influence of oceanographic processes on pelagic-benthic coupling in polar regions: a benthic perspective. J. Mar. Syst. 2, 495-518. doi: 10.1016/0924-7963(91)90049-Z

Grebmeier, J. M., Cooper, L. W., Feder, H. M., and Sirenko, B. I. (2006). Ecosystem dynamics of the Pacific-influenced Northern Bering and Chukchi Seas in the Amerasian Arctic. Prog. Oceanogr. 71, 331-361. doi: $10.1016 /$ j.pocean.2006.10.001

Hobson, K. A., Ambrose, W. G., and Renaud, P. E. (1995). Sources of primary production, benthic-pelagic coupling, and trophic relationships within the Northeast Water Polynya: insights from $\delta^{13} \mathrm{C}$ and $\delta^{15} \mathrm{~N}$ analysis. Mar. Ecol. Prog. Ser. 128, 1-10. doi: 10.3354/meps 128001

Hobson, K. A., Fisk, A., Karnovsky, N., Holst, M., Gagnon, J. M., and Fortier, M. (2002). A stable isotope $\left(\delta^{13} \mathrm{C}\right.$ and $\left.\delta^{15} \mathrm{~N}\right)$ model for the North Water food web: implications for evaluating trophodynamics and the flow of energy and contaminants. Deep Sea Res. Part II Top. Stud. Oceanogr. 49, 5131-5150. doi: 10.1016/S0967-0645(02)00182-0
Iken, K., Bluhm, B., and Dunton, K. (2010). Benthic food-web structure under differing water mass properties in the southern Chukchi Sea. Deep Sea Res. Part II Top. Stud. Oceanogr. 57, 71-85. doi: 10.1016/j.dsr2.2009.08.007

Iken, K., Bluhm, B. A., and Gradinger, R. (2005). Food web structure in the high Arctic Canada Basin: evidence from $\delta^{13} \mathrm{C}$ and $\delta^{15} \mathrm{~N}$ analysis. Polar Biol. 28, 238-249. doi: 10.1007/s00300-004-0669-2

Kędra, M., Kuliñski, K., Walkusz, W., and Lege ¿yñska, J. (2012). The shallow benthic food web structure in the high Arctic does not follow seasonal changes in the surrounding environment. Estuar. Coast. Shelf Sci. 114, 183-191. doi: 10.1016/j.ecss.2012.08.015

Kędra, M., Renaud, P., Andrade, H., Goszczko, I., and Ambrose, W. Jr. (2013). Benthic community structure, diversity, and productivity in the shallow Barents Sea bank (Svalbard Bank). Mar. Biol. 160, 805-819. doi: 10.1007/s00227-0122135-y

Kortsch, S., Primicerio, R., Beuchel, F., Renaud, P. E., Rodrigues, J., Lonne, O. J., et al. (2012). Climate-driven regime shifts in Arctic marine benthos. Proc. Natl. Acad. Sci. U.S.A. 109, 14052-14057. doi: 10.1073/pnas.1207509109

Krause-Jensen, D., Marba, N., Olesen, B., Sejr, M. K., Christensen, P. B., Rodrigues, J., et al. (2012). Seasonal sea ice cover as principal driver of spatial and temporal variation in depth extension and annual production of kelp in Greenland. Glob. Change Biol. 18, 2981-2994. doi: 10.1111/j.1365-2486.2012. 02765.x

Krumhansl, K. A., Lauzon-Guay, J.-S., and Scheibling, R. E. (2014). Modeling effects of climate change and phase shifts on detrital production of a kelp bed. Ecology 95, 763-774. doi: 10.1890/13-0228.1

Link, H., Archambault, P., Tamelander, T., Renaud, P. E., and Piepenburg, D. (2011). Spring-to-summer changes and regional variability of benthic processes in the western Canadian Arctic. Polar Biol. 34, 2025-2038. doi: 10.1007/s00300011-1046-6

Mateo, M. A., Serrano, O., Serrano, L., and Michener, R. H. (2008). Effects of sample preparation on stable isotope ratios of carbon and nitrogen in marine invertebrates: implications for food web studies using stable isotopes. Oecologia 157, 105-115. doi: 10.1007/s00442-008-1052-8

McMahon, K. W., Ambrose, W. G. Jr., Johnson, B. J., Sun, M.-Y., Lopez, G. R., Clough, L. M., et al. (2006). Benthic community response to ice algae and phytoplankton in Ny Ålesund, Svalbard. Mar. Ecol. Prog. Ser. 310, 1-14. doi: 10.3354/meps310001

McMeans, B. C., Rooney, N., Arts, M. T., and Fisk, A. T. (2013). Food web structure of a coastal Arctic marine ecosystem and implications for stability. Mar. Ecol. Prog. Ser. 482, 17-28. doi: 10.3354/meps10278

McTigue, N. D., Bucolo, P., Liu, Z., and Dunton, K. H. (2015). Pelagic-benthic coupling, food webs, and organic matter degradation in the Chukchi Sea: insights from sedimentary pigments and stable carbon isotopes. Limnol. Oceanogr. 60, 429-445. doi: 10.1002/lno.10038

Michener, R. H., Kaufman, L., Michener, R., and Lajtha, K. (2007). Stable isotope ratios as tracers in marine food webs: an update. Stab. Isot. Ecol. Environ. Sci. 238-282. doi: 10.1002/9780470691854.ch9

Moore, J. C., Berlow, E. L., Coleman, D. C., Ruiter, P. C., Dong, Q., Hastings, A., et al. (2004). Detritus, trophic dynamics and biodiversity. Ecol. Lett. 7, 584-600. doi: 10.1111/j.1461-0248.2004.00606.x

Morata, N., and Renaud, P. E. (2008). Sedimentary pigments in the western Barents Sea: a reflection of pelagic-benthic coupling? Deep Sea Res. Part II Top. Stud. Oceanogr. 55, 2381-2389. doi: 10.1016/j.dsr2.2008.05.004

Morata, N., Renaud, P. E., Brugel, S., Hobson, K. A., and Johnson, B. J. (2008). Spatial and seasonal variations in the pelagic-benthic coupling of the southeastern Beaufort Sea revealed by sedimentary biomarkers. Mar. Ecol. Prog. Ser. 371, 47-63. doi: 10.3354/meps07677

Nadon, M.-O., and Himmelman, J. H. (2006). Stable isotopes in subtidal food webs: have enriched carbon ratios in benthic consumers been misinterpreted? Limnol. Oceanogr. 51, 2828-2836. doi: 10.4319/lo.2006.51.6.2828

Nakatsuka, T., Handa, N., Harada, N., Sugimoto, T., and Imaizumi, S. (1997). Origin and decomposition of sinking particulate organic matter in the deep water column inferred from the vertical distributions of its $\delta^{15} \mathrm{~N}, \delta^{13} \mathrm{C}$ and $\delta^{14} \mathrm{C}$. Deep Sea Res. I 44, 1957-1979. doi: 10.1016/S0967-0637(97)00051-4

Nerot, C., Lorrain, A., Grall, J., Gillikin, D. P., Munaron, J.-M., Le Bris, H., et al. (2012). Stable isotope variations in benthic filter feeders across a large depth gradient on the continental shelf. Estuar. Coast. Shelf Sci. 96, 228-235. doi: 10.1016/j.ecss.2011.11.004 
Nilsen, F., Cottier, F., Skogseth, R., and Mattsson, S. (2008). Fjord-shelf exchanges controlled by ice and brine production: the interannual variation of Atlantic Water in Isfjorden, Svalbard. Cont. Shelf Res. 28, 1838-1853. doi: 10.1016/j.csr.2008.04.015

Norkko, A., Thrush, S., Cummings, V., Gibbs, M., Andrew, N., Norkko, J., et al. (2007). Trophic structure of coastal Antarctic food webs associated with changes in sea ice and food supply. Ecology 88, 2810-2820. doi: 10.1890/061396.1

Peterson, B. J., and Fry, B. (1987). Stable isotopes in ecosystem studies. Annu. Rev. Ecol. Syst. 293-320. doi: 10.1146/annurev.es.18.110187.001453

Piepenburg, D. (2005). Recent research on Arctic benthos: common notions need to be revised. Polar Biol. 28, 733-755. doi: 10.1007/s00300-005-0013-5

Post, D. M. (2002). Using stable isotopes to estimate trophic position: models, methods, and assumptions. Ecology 83, 703-718. doi: 10.1890/00129658(2002)083[0703:USITET]2.0.CO;2

Post, D. M., Layman, C. A., Arrington, D. A., Takimoto, G., Quattrochi, J., and Montana, C. G. (2007). Getting to the fat of the matter: models, methods and assumptions for dealing with lipids in stable isotope analyses. Oecologia 152, 179-189. doi: 10.1007/s00442-006-0630-x

Reigstad, M., Wexels-Riser, C., Wassmann, P., and Ratkova, T. (2008). Vertical export of particulate organic carbon: attenuation, composition and loss rates in the northern Barents Sea. Deep-Sea Res. 55, 2308-2319. doi: 10.1016/j.dsr2. 2008.05.007

Renaud, P. E., Morata, N., Carroll, M. L., Denisenko, S. G., and Reigstad, M. (2008). Benthic-pelagic coupling in the western Barents Sea: processes and time scales. Deep-Sea Res. 55, 2372-2380. doi: 10.1024/j.dsr2.2008.05.017

Renaud, P. E., Tessmann, M., Evenset, A., and Christensen, G. N. (2011). Benthic food-web structure of an Arctic fjord (Kongsfjorden, Svalbard). Mar. Biol. Res. 7, 13-26. doi: 10.1080/17451001003671597

Renaud, P. E., Sejr, M. K., Bluhm, B. A., Sirenko, B. I., and Ellingsen, I. H. (in press). The future of Arctic benthos. Progr. Oceanogr.

Roy, V., Iken, K., and Archambault, P. (2014). Environmental drivers of the Canadian Arctic megabenthic communities. PLoS ONE 9:e100900. doi: 10.1371/journal.pone.0100900

Sokołowski, A., Wołowicz, M., Asmus, H., Asmus, R., Carlier, A., Gasiunaite, Z., et al. (2012). Is benthic food web structure related to diversity of marine macrobenthic communities? Estuar. Coast. Shelf Sci. 108, 76-86. doi: 10.1016/j. ecss.2011.11.011

Søreide, J. E., Hop, H., Carroll, M. L., Falk-Petersen, S., and Hegseth, E. N. (2006a). Seasonal food-web structures and sympagic-pelagic coupling in the European
Arctic revealed by stable isotopes and a two-source food web model. Prog Oceanogr. 71, 59-87. doi: 10.1016/j.pocean.2006.06.001

Søreide, J. E., Tamelander, T., Hop, H., Hobson, K. A., and Johansen, I. (2006b). Sample preparation effects on stable $\mathrm{C}$ and $\mathrm{N}$ isotope values: a comparison of methods in Arctic marine food web studies. Mar. Ecol. Prog. Ser. 328, 17-28. doi: 10.3354/meps328017

Tamelander, T., Renaud, P. E., Hop, H., Carroll, M. L., Ambrose, W. G., and Hobson, K. A. (2006). Trophic relationships and pelagic-benthic coupling during summer in the Barents Sea Marginal Ice Zone, revealed by stable carbon and nitrogen isotope measurements. Mar. Ecol. Progr. Ser. 310, 33-46. doi: $10.3354 /$ meps 310033

Vetter, E. W., and Dayton, P. K. (1998). Macrofaunal communities within and adjacent to a detritus-rich submarine canyon system. Deep Sea Res. Part II 45, 25-54. doi: 10.1016/S0967-0645(97)00048-9

Weslawski, J., Wiktor, J. Jr., and Kotwicki, L. (2010). Increase in biodiversity in the arctic rocky littoral, Sorkappland, Svalbard, after 20 years of climate warming. Mar. Biodiv. 40, 123-130. doi: 10.1007/s12526-010-0038-Z

Węsławski, J. M., Kendall, M. A., Włodarska-Kowalczuk, M., Iken, K., Kẽdra, M., Legeźyńska, J., et al. (2011). Climate change effects on Arctic fjord and coastal macrobenthic diversity-observations and predictions. Mar. Biodiv. 41, 71-85. doi: 10.1007/s12526-010-0073-9

Wexels Riser, C., Wassmann, P., Reigstad, M., and Seuthe, L. (2008). Vertical flux regulation by zooplankton in the northern Barents Sea during Arctic spring. Deep Sea Res. II 55, 2320-2329. doi: 10.1016/j.dsr2.2008.05.006

Woelfel, J., Schumann, R., Peine, F., Flohr, A., Kruss, A., Tegoski, J., et al. (2010). Microphytobenthos of Arctic Kongsfjorden (Svalbard, Norway): biomass and potential primary production along the shore line. Polar Biol. 33, 1239-1253. doi: $10.1007 / \mathrm{s} 00300-010-0813-0$

Conflict of Interest Statement: The authors declare that the research was conducted in the absence of any commercial or financial relationships that could be construed as a potential conflict of interest.

Copyright (C) 2015 Renaud, Løkken, Jørgensen, Berge and Johnson. This is an openaccess article distributed under the terms of the Creative Commons Attribution License (CC BY). The use, distribution or reproduction in other forums is permitted, provided the original author(s) or licensor are credited and that the original publication in this journal is cited, in accordance with accepted academic practice. No use, distribution or reproduction is permitted which does not comply with these terms. 


\section{Appendix}

TABLE A1 | List of abbreviations used for taxa in Figure 4 and the taxon and larger taxonomic group referred to.

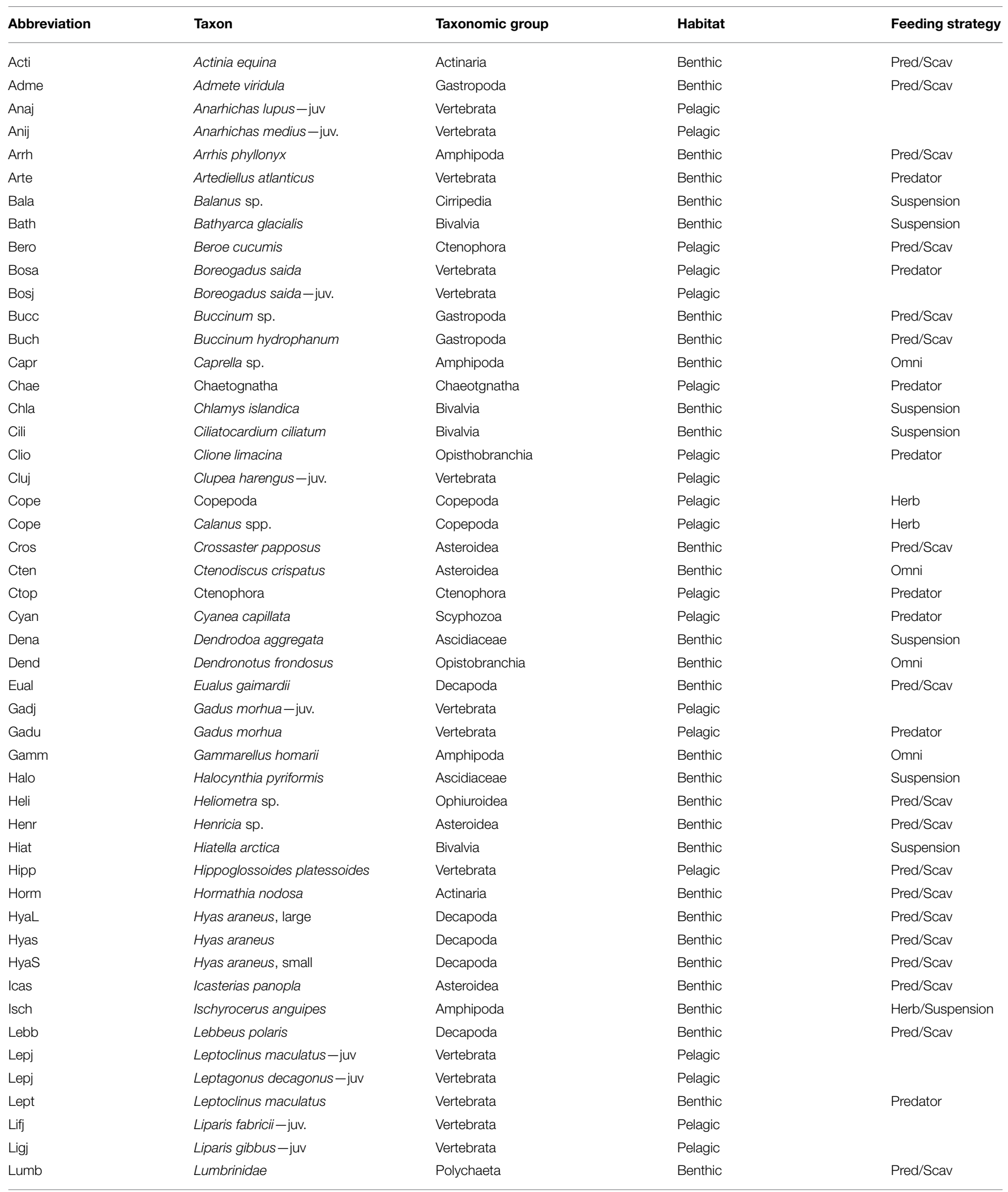


TABLE A1 | Continued

\begin{tabular}{|c|c|c|c|c|}
\hline Abbreviation & Taxon & Taxonomic group & Habitat & Feeding strategy \\
\hline Lumj & Lumpenus lampretaeformis - juv. & Vertebrata & Pelagic & \\
\hline Lump & Lumpenus lampretaeformis & Vertebrata & Benthic & Predator \\
\hline Lyco & Lycodes sp. & Vertebrata & Benthic & Pred/Scav \\
\hline Maid & Maldanidae & Polychaeta & Benthic & Omni \\
\hline Mald & Maldane sarsii & Polychaeta & Benthic & Omni \\
\hline Mals & Maldane sp. & Polychaeta & Benthic & Omni \\
\hline Mega & Megalopa & Decapoda & Pelagic & \\
\hline Mela & Melanogrammus aeglefinus & Vertebrata & Pelagic & Predator \\
\hline Mert & Mertensia ovum & Ctenophora & Pelagic & Pred/Scav \\
\hline Musc & Musculus sp. & Bivalvia & Benthic & Suspension \\
\hline Nere & Nereis zonata & Polychaeta & Benthic & Omni \\
\hline Noth & Nothria sp. & Polychaeta & Benthic & Pred/Scav \\
\hline Nucu & Nuculana pernula & Bivalvia & Benthic & Suspension \\
\hline Nymp & Nymphon sp. & Pycnogonida & Benthic & Pred/Scav \\
\hline Opac & Ophiopholis aculeata & Ophiuroidea & Benthic & Omni \\
\hline Opbi & Ophiacantha bidentata & Ophiuroidea & Benthic & Omni \\
\hline Opgl & Ophioscolex glacialis & Ophiuroidea & Benthic & Omni \\
\hline Opsa & Ophiura sarsii & Ophiuroidea & Benthic & Omni \\
\hline Opse & Ophiocten sericeum & Ophiuroidea & Benthic & Omni \\
\hline Pagu & Pagurus pubescens & Decapoda & Benthic & Pred/Scav \\
\hline Pand & Pandalus borealis & Decapoda & Benthic & Pred/Scav \\
\hline Reij & $\begin{array}{l}\text { Reinhardtius } \\
\text { hippoglossoides_juv. }\end{array}$ & Vertebrata & Pelagic & \\
\hline Rein & Reinhardtius hippoglossoides & Vertebrata & Pelagic & Predator \\
\hline Rhac & Rhachotropis inflata & Amphipoda & Benthic & Pred/Scav \\
\hline Sabe & Sabellidae & Polychaeta & Benthic & Suspension \\
\hline Sabi & Sabinea septemcarinata & Decapoda & Benthic & Pred/Scav \\
\hline Saga & Sagartia troglodytes & Actinaria & Benthic & Pred/Scav \\
\hline Sagi & Sagitta elegans & Chaeotgnatha & Pelagic & Pred/Scav \\
\hline Sars & Sarsia sp. & Hydrozoa & Pelagic & Predator \\
\hline Seba & Sebastes mentella & Vertebrata & Pelagic & Predator \\
\hline Seba & Sebastes mentella-small & Vertebrata & Pelagic & \\
\hline Semi & Semibalanus balanoides & Cirripedia & Benthic & Suspension \\
\hline Sepi & Sepiola sp. & Cephalopoda & Bentho-pelagic & Predator \\
\hline Simi & Similipecten greenlandicus & Bivalvia & Benthic & Suspension \\
\hline Soca & Socarnes sp. & Amphipoda & Benthic & Pred/Scav \\
\hline Spir & Spirontocaris sp. & Decapoda & Benthic & Predator \\
\hline Spon & Sponge P21 & Porifera & Benthic & Suspension \\
\hline
\end{tabular}


TABLE A1 | Continued

\begin{tabular}{lllll}
\hline Abbreviation & Taxon & Taxonomic group & Habitat & Feeding strategy \\
\hline Stro & Strongylocentrotus sp. & Echinoidea & Benthic & Grazer/Omni \\
Syno & Synoicum turgens & Ascidiaceae & Benthic & Suspension \\
Test & Testudinalia testudinalis & Gastropoda & Benthic & Prazer \\
Thea & Themisto abyssorum & Amphipoda & Pelagic & Suspension \\
Thec & Thelepus cincinnatus & Polychaeta & Benthic & Predator \\
Thel & Themisto libellulida & Amphipoda & Pelagic & Pred/Scav \\
Them & Themisto sp. & Amphipoda & Pelagic & Pred/Scav \\
Thin & Thysanoessa inermis & Euphausiacea & Pelagic & Pred/Scav \\
Thys & Thysanoessa sp. & Euphausiacea & Benthic & Pred/Scav \\
Urti & Urticina eques & Actinaria & Benthic & Predator \\
Velu & Velutina sp. & Gastropoda &
\end{tabular}

Primary habitat is also shown, along with presumed general feeding strategy. Pred/Sav, Predator/Scavenger; Omni, Omnivore; Herb, Herbivore. 